\title{
Heat Treatment of Steel 1.1730 with Concentrated Solar Energy
}

\author{
MARIA STOICANESCU ${ }^{1}$, AUREL CRISAN ${ }^{1}$, IOAN MILOSAN ${ }^{1}$, MIHAI ALIN POP1*, JOSE RODRIGUEZ GARCIA ${ }^{2}$, IOAN GIACOMELLI ${ }^{1}$, \\ TIBOR BEDO ${ }^{1}$, INMACULADA CANADAS MARTINEZ ${ }^{2}$, AUGUSTIN SEMENESCU ${ }^{3}$, BOGDAN FLOREA ${ }^{3}$, OANA ROXANA CHIVU 4 \\ ${ }^{1}$ Transilvania University of Brasov, Faculty of Materials Science and Engineering, Department of Materials Science, 1 Colina \\ Universitatii Str., 500084, Brasov, Romania \\ 2Plataforma Solar de Almeria, Spain \\ 3University Politehnica of Bucharest, Faculty of Material Science and Engineering, 313 Splaiul Independentei, 060021, Bucharest, \\ Romania \\ ${ }^{4}$ University Politehnica of Bucharest, Faculty of Engineering and Management of Technological Systems, 313 Splaiul Independentei, \\ 060021, Bucharest, Romania
}

\begin{abstract}
This paper presents and discusses research conducted with the purpose of developing the use of solar energy in the heat treatment of steels. For this, a vertical axis solar furnace called at Plataforma Solar de Almeria was adapted such as to allow control of the heating and cooling processes of samples made from 1.1730 steel. Thus temperature variation in pre-set points of the heated samples could be monitored in correlation with the working parameters: the level of solar radiation and implicitly the energy used the conditions of sample exposed to solar radiation, and the various protections and cooling mediums. The recorded data allowed establishing the types of treatments applied for certain working conditions. The distribution of hardness, as the representative feature resulting from heat treatment, was analysed on all sides of the treated samples. In correlation with the time-temperature-transformation diagram of 1.1730 steel, the measured values confirmed the possibility of using solar energy in all types of heat treatment applied to this steel. In parallel the efficiency of using solar energy was analysed in comparison to the energy obtained by burning methane gas for the heat treatmentfor the same set of samples. The analysis considered energy consumption, productivity and the impact on the environment. Thanks to various data obtained through developed experiences, which cover a wide range of thermic treatments applied steels 1.1730 model, we can certainly state that this can be a solid base in using solar energy in applications of thermic treatment at a high industrial level.
\end{abstract}

Keywords: Solar energy, Heattreatment, Hardness, 1.1730 Steel

The concept of clean technologies (hypo-polluting, with minimal loss) refers to non-polluting technologies that generate less waste, entail minimum material and energy consumption with the least impact on the environment and pose reduce ecological risks.

In addition to the field of environment conservation, clean technologies cover several aspects of actual economic activity as well. The concept is based on the premise that it is easier and cheaper to prevent, than to repairpollution.

Thus reducing pollution at the source becomes a requirementfor the entire technical and economic activity, leading to both an optimised and environment-friendly production.

A concrete case of clean technology deployment in industry is applying solar energy to heat treatments. Byproducts of heat treatment in traditional furnaces using gas fuel are emissions of $\mathrm{CO}, \mathrm{CO}_{2}, \mathrm{SO}_{x^{\prime}} \mathrm{NO}$ released into the air and endangering worker health as well as the entire ecosystem of the respective area, mainly because $\mathrm{CO}_{2}$ is the principal gas responsible for the greenhouse effect [23]

Over the past half century large quantities of carbon dioxide and methane have been released into the atmosphere, reducing atmosphere permeability to the caloric radiations reflected by Earth into the cosmic space. This has initiated the phenomenon known as global warming [6].

Unlike traditional technologies, the utilisation of clean technologies, namely of solar energy based heat treatments, does not yield gas emissions, thus protecting working personnel as well as the environment $[1,20]$.

Heat treatments are metallurgical procedures applied to metal alloys, and mainly to those with solid state phase transformations, causing structural modifications and consequently improvement of their properties in industrial applications. Their great diversity is due to the fact that each alloy (by the group of its base metal, its chemical composition and obtaining history) has the particularities of the phase transformation mechanisms. For Fe-C alloys (steel and cast iron) the time-temperature-transformation (CCT) diagrams feature information useful for heat treatment procedures [2]. According to the specific requirements, heat treatments cause uniform structural modifications in the entire volume of the parts or only in certain areas, like their surface. In order to enable such specific treatments the available equipment, heat sources and experimental procedures need to be adapted.

The energy required for heat treatment can be of most varied origin, from the direct burning of classic fuels (methane gas, crude oil), to multiple variants of electric energy converted to heat (in resistors, by induction, or electric arc). For superficial heat treatments, in addition to the classic variants of heating by flame, by electric arc or by electromagnetic induction, an increasing number of plasma and lately solar energy based variants have been developed [3, 6, 8, 10, 21, 25]. As a practically inexhaustible and at the same time completely ecologically obtained source, solar energy has been in the focus of researchers in view of deployment in metal processing for a longer period of time [20]. Several variants of furnaces with varied performance were developed in order to obtain concentrated solar energy (CSE) applied to the surface of treated parts $[9,17]$. This energy can be used for multiple purposes: surface melting and alloying $[3,6,18,25]$, welding [8] and heat treatment [4, 9, 10-12, 14, 22, 24].

* email: mihai.pop@unitbv.ro

MATERIALE PLASTICE $\diamond$ 56. No. 1 2019 http://www.revmaterialeplastice.ro 
Although the first attempts of using solar energy for treating metals are quite old [20], the results yielded by research over time have not materialised in technology breakthroughs with significant industrial applications. Experiments conducted on various types of materials (steels, cast irons, non-ferrous alloys) were aimed mainly at revealing the adaptability of certain solar furnace constructive particularities $[9,17]$, such as to ensure the concentration of solar energy for the intended processes. In the case of steels the tests carried out on generally small samples (of 30 - $45 \mathrm{~mm}$ diameter and $1.5-100 \mathrm{~mm}$ length) $[9,12,13,22]$ have demonstrated the possibility of performing typical heat treatments (superficial or in-depth hardenings) applied mostoften statically. The experiments revealed the possibility of obtaining the desired structures and properties of the treated materials, while benefitting from the advantages offered by concentrated solar energy. The most important advantage is the high heating rate of the surfaces exposed to the spot of concentrated solar energy.

Highly important in industrial applications is the of solar energy based clean technologies such as to satisfy the requirements of various products, whose properties are to be obtained by heat treatment. For this reason the presented research was focused on the utilisation of clean technologies by means of a technologically adapted furnace that allows linking the working method and heat treatment parameters (temperature, heating and cooling rates) to the final properties (hardness) of the part. Rectangular block shaped samples made from 1.1730 steel $(0.45 \% \mathrm{C} ; 0.30 \% \mathrm{Si} ; 0.70 \% \mathrm{Mn})$ were subjected to heat treatments carried out in static and dynamic conditions used.

The paper relates to the following directions of research:

- study of the solar energy efficiency in the variant of direct light spot heating for performing various heat treatments of metallic materials, in the present case of 1.1730 steel;

- obtaining experimental data in order to apply thermic treatments with the help of solar energy to steel 1.1730.

- integration of the utilisation of solar energy for the specific heat treatment of 1.1730 steel into the category of clean technologies, proving its benefits as to both noxious emissions and economic efficiency.

\section{Experimental part}

The experimental research used the solar energy capturing installation SF-5 (Solar Furnace 5) at Plataforma Solar Almeria, Spain. The furnace, by its $5 \mathrm{~kW}$ power, reaches a concentration of above 6000 suns, and is mainly devoted for materials treatmentat high temperature, under vacuum and controlled atmosphere conditions. In comparison to conventional furnaces, solar furnaces provide higher thermal fluxes (black body temperatures of up to $3,600 \mathrm{~K}$ can be attained), they ensure higher heating rates and are environmentally friendly. The main components of SF-5 are heliostat, concentrator, attenuator, test table, and a gas system. The main technical characteristics of the concentrator are Diameter: $3.5 \mathrm{~m}$ Projected area $8.77 \mathrm{~m}^{2}$. Focal distance $2 \mathrm{~m} \cdot \mathrm{f} / \mathrm{d}$ ratio: $0.57 \cdot$ RIM angle: $54.4^{\circ}$. Total power: $5 \mathrm{~kW}$ - Peak concentration: $6,000 \mathrm{~kW} / \mathrm{m}^{2}$.

The attenuator is located between the heliostat and the concentrator, and consists of a set of metal slats by means of which the power provided to the sample can be varied between 0 and $100 \%$ in about $7 \mathrm{~s}$ [13]. It can be adjusted both manually and automatically via the installation's control system.

The SCADA data acquisition and control system is installed in the PC placed in the control room and is connected through Ethernet to an Allen Bradley PLC. This allows control by three axes of the table position (sample position in relation to the solar energy spot) and of the attenuator (the degree of attenuator opening). The acquisition system includes tw 0 Solartron IMP cards of 20 channels each, by means of which the most important variables can be recorded during the experiment, related to the environment, the conditions of exposure of the studied sample and certain parameters monitored in the sample [13].

The samples were heated in two variants:

-by maintaining the sample in a fixed exposure position to the spot of solar energy;

-by moving the sample with a velocity of $720 \mathrm{~mm} / \mathrm{h}$ along a horizontal axis ( $\mathrm{X}$ axis) during exposure to the solar spot.

In order to carry out the experiments a number of devices were adapted, namely for sample temperature recording during heat treatment ( $K$ thermocouple) and for cooling conditions control. These devices are described as part of the presentation of each conducted experiment.

Table 1 shows form and dimensions of the samples used in the study.

Four variants of experiments described further on were designed such as to cover all types of heat treatment specific to steel 1.1730, described in the CCT diagram of figure 4. Each of the experiments used adequate samples for the respective purpose (table 1). In each experiment the solar spot heated the sample surface at the smallest distance from the mounting position of the thermocouples (1 $\mathrm{mm}$ ).

Experiment 1 was performed on samples 1 and 2 (table 1) by moving the concentrated light spot along the sample surface. The samples were placed in the facility as shown in figure $1 b$, on a copper support placed on the test table. The supportincludes the set of thermocouples responsible for measuring the evolution of temperature in the samples during the experiment (fig. 1a).

The heating of the samples started with the concentrated light spot positioned in the area above the

\begin{tabular}{|c|c|c|c|c|c|}
\hline $\begin{array}{c}\text { Sample } \\
\text { no. }\end{array}$ & \multicolumn{3}{|c|}{ Sample form and dimensions [mm] } & Experiment \\
\hline 1,2 & & & & & \\
\hline
\end{tabular}

Table 1

THE SAMPLES SHAPEAND DIMENSIONS 


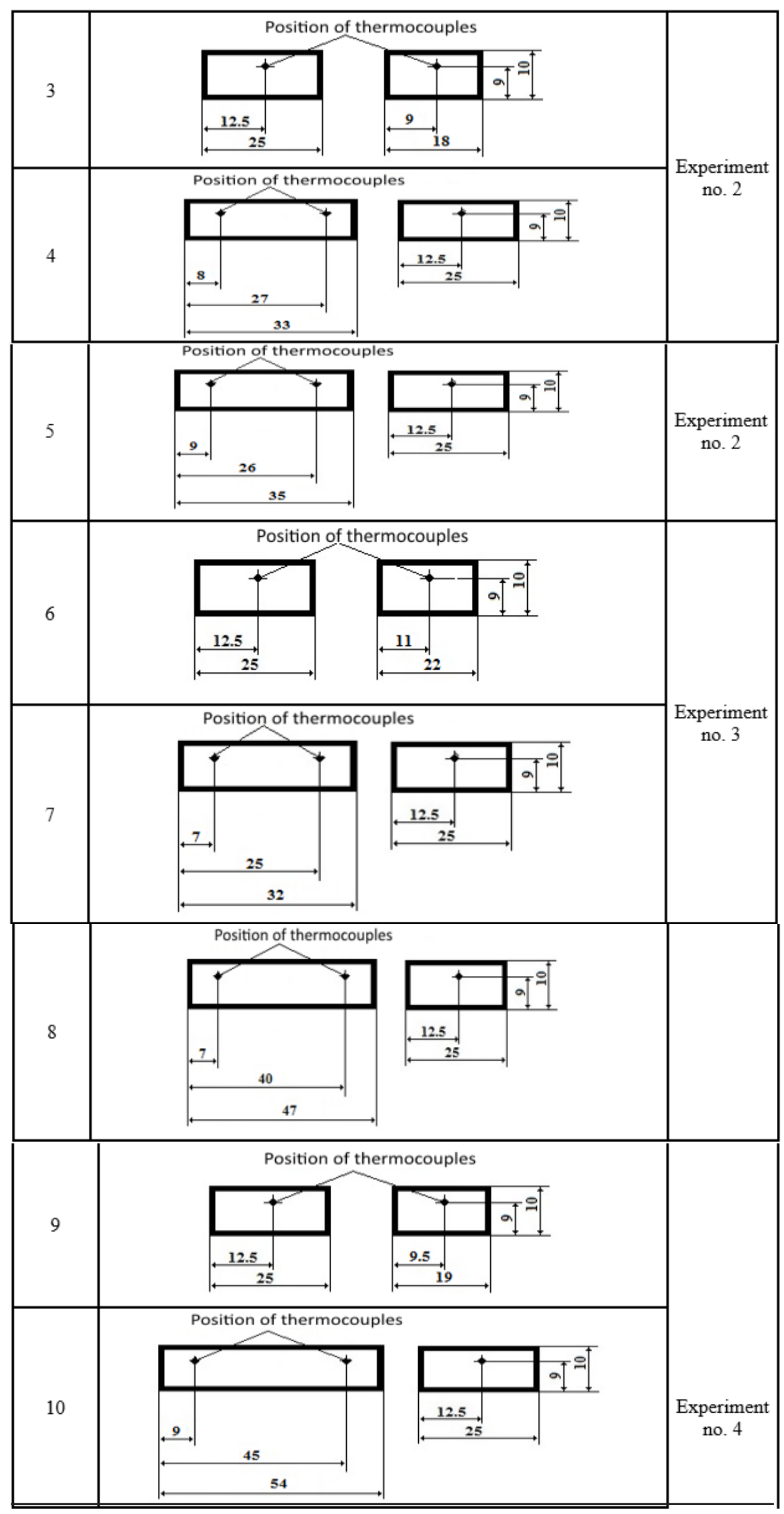

Table 1

CONTINUATED 


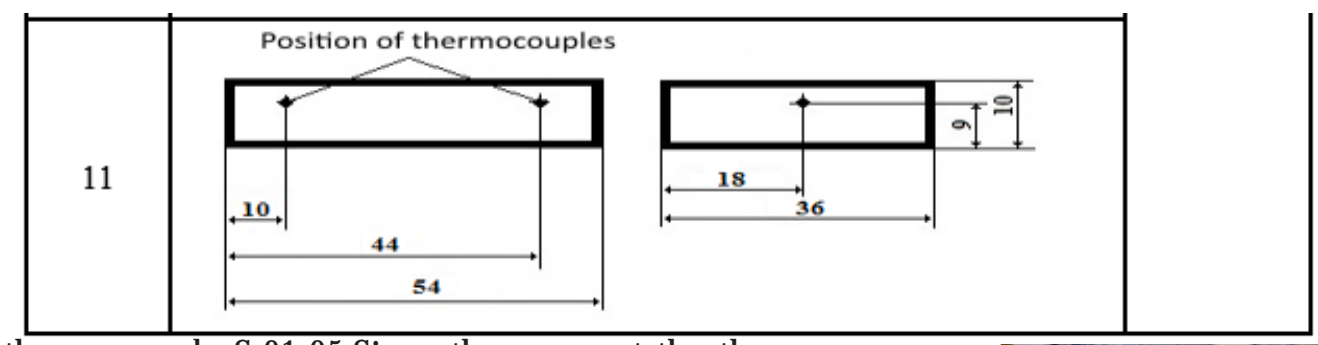

Table 1

CONTINUATED

thermocouple S-01-05.Since the moment the thermocouple indicated the preset temperature $\left(930^{\circ} \mathrm{C}\right)$, the sample was maintained in that position for $15 \mathrm{~s}$, which after the test table was set into motion by a velocity of 720 $\mathrm{mm} / \mathrm{h}$. Once the concentrated light spot reached the other end of the sample, above thermocouple S-01-01, it was

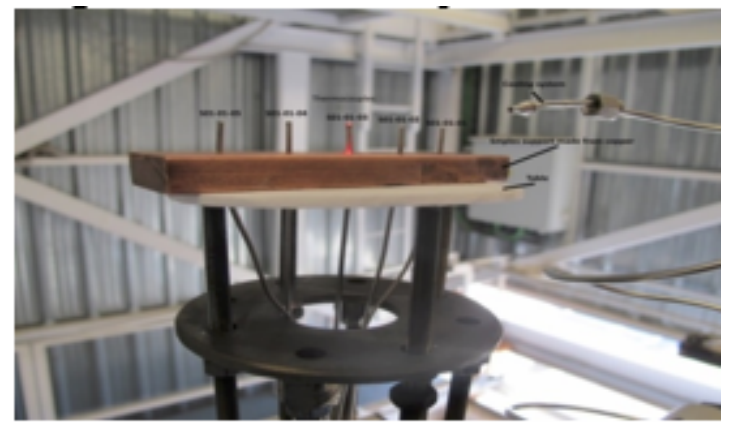

a)

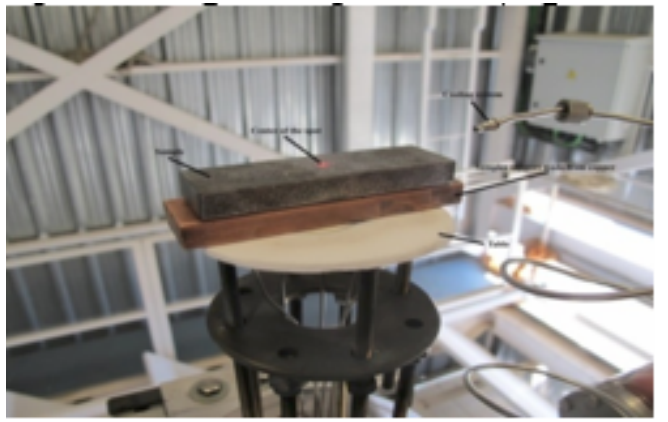

b)

Fig. 1. Location area of the samples in the installation. a) support including the set of thermocouples, b) sample placed on the support

maintained fixed in this position until this thermocouple indicated the temperature of reference $\left(930^{\circ} \mathrm{C}\right)$. After another $45 \mathrm{~s}$ of extended maintaining time, the sample was cooled with technical air sprayed directly onto it by means of the specially developed device (shown in fig. 1). The data related to this experiment, recorded by the command and control system are presented in figure 5 .

Experiment 2, was performed on samples 3, 4 and 5 (table 1), of smaller dimensions than those of the samples used in the previous experiment. An anti-oxidation protection system was in place during the heating of the samples. This is a component of the installation gas system and consists of a DURAN 5 l borosilicate sphere where $\mathrm{N}_{2}$ atmosphere was created (fig. 2).

The light spot was maintained fixed in their central position on sample 3 (with one thermocouple) and 4 (with tw o thermocouples), for $15 \mathrm{~s}$, after the temperature indicated by the thermocouple had reached the reference value $\left(930^{\circ} \mathrm{C}\right)$. For sample 5 heating started at one extremity of the sample (above the position of thermocouple S-01$01)$. After having reached the reference temperature of $930{ }^{\circ} \mathrm{C}$ the sample was maintained in that position for another $15 \mathrm{~s}$, followed by displacement by $720 \mathrm{~mm} / \mathrm{h}$, until the concentrated light spot arrived above the position of

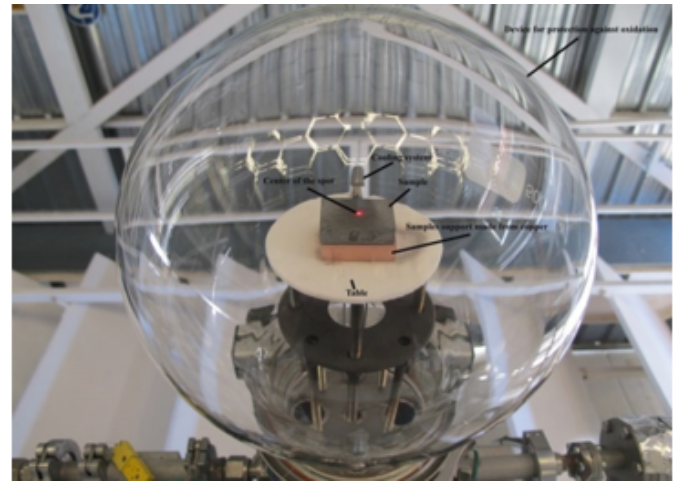

Fig.2. Experimental setup for variant 2

thermocouple S-01-05. Once the temperature indicated by thermocouple S-01-05 reached the reference value of $930^{\circ} \mathrm{C}$, heating continued for another $15 \mathrm{~s}$. The samples in this experiment were cooled by spraying air flow projected directly onto the samples by means of a device adapted to the test bed (fig. 2). Figure 6 shows the data of the experiment recorded by the command and control system.

From the viewpoint of heating Experiment 3 was performed under similar conditions as experiment 2 (for samples 6 and 7 the light spot was maintained fixed over the central position, and sample 8 was heated similarly as sample 5). Cooling was achieved by spraying a mixture of argon and water directly upon the samples. Figure 7 shows the data of the experiment recorded by the control and command system.

Experiment 4 required a series of constructive adjustments of the installation. In this case the test table consisted of two mobile (hinge type) parts with the possibility of rotation in a vertical plane, such as to allow the free fall of the samples into a cooling bath (fig. 3). Antioxidation protection during heating was ensured by an $\mathrm{Ar}$ environment sprayed continuously into the sample area. The samples were heated similarly to the procedure used in experiments 2 and 3 . For samples 9 and 10 the light spot was maintained in a fixed position (the central area of the sample upper surface). After having reached the reference temperature of $930^{\circ} \mathrm{C}$, it was keptfor another $15 \mathrm{~s}$, followed by cooling. Sample 11 was heated similarly to that of sample 5 of experiment 2 and sample 8 of experiment 3 . Cooling took place in an Ar bubbled water bath with an initial temperature of $10^{\circ} \mathrm{C}$. In each case, upon completion of the heating cycle, the actuation of the test table caused the free fall of the samples together with the attached thermocouples into the cooling bath. Figure 8 shows the data of the experiment recorded by the command and control system.

\section{Results and discussions}

The above described experimenting conditions were pre-set, such as to ensure the possibility of applying the main types of heat treatment to steel 1.1730. For a correct evaluation of the type of heat treatment in each experiment the evolution of temperature in the samples was compared to the CCT diagram shown in figure 4. The processed data from this diagram yielded three cooling rate ranges in the 


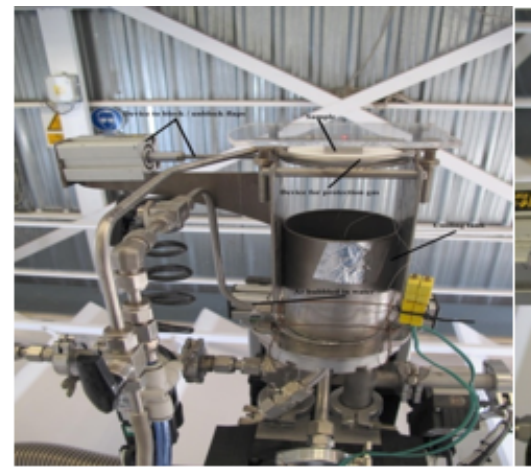

a)

Continuous Cooling Transformation Diagram (CCT)

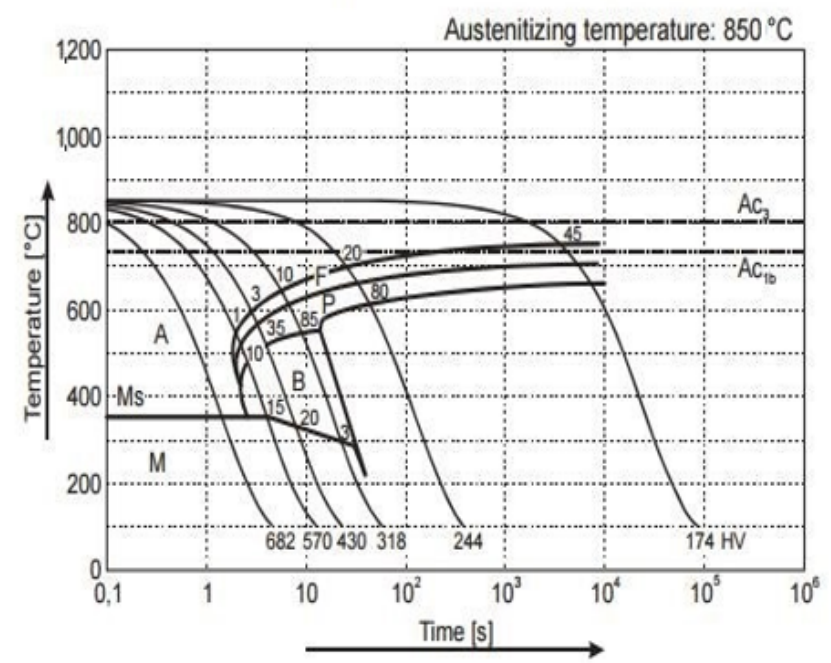

Fig.4. CCT diagram for 1.1730 steel [2]

austenite region, corresponding to three specific structure and hardness regions, respectively (converted from $\mathrm{HV}$ to $\mathrm{HRC}$ ), as follows:

- cooling rates smaller than $30,600^{\circ} \mathrm{C} / \mathrm{h}$, corresponding to normalization annealing and determining (ferrite pearlite) structures of hardness smaller than $21 \mathrm{HRC}$;

- cooling rates ranging from 30,600 to $354,000{ }^{\circ} \mathrm{C} / \mathrm{h}$, typical for intermediary treatments aimed at generating structures made up nodular pearlite, sorbite, troostite, bainite, of hardness ranging from 21 to $55 \mathrm{HRC}$;

- cooling rates greater than $354,000^{\circ} \mathrm{C} / \mathrm{h}$, typical for hardening, generating martensitic structures of hardness over 55 HRC.

Recorded working parameters and the corresponding heating/cooling rates

By means of the data acquisition and control system for each experiment a data base was recorded with information on the working parameters' evolution versus time. Figures 5 to 8 present the graphs corresponding to
Fig. 3 Installation adapted for experiment 4: a) mounting of the sample at heating; b) sample plunged into the cooling tank containing $\mathrm{Ar}$ bubbled water

these data. From each experiment's data base the values of the temperatures in the samples and their corresponding times were extracted, required for the calculation of the average heating and cooling rates, respectively, for the critical temperature intervals. For each experiment the type of applied heat treatment was established by comparing the cooling rates with those specific of the CCT diagram in figure 4.

Figure 5 shows for experiment 1 the diagrams of temperature evolution in the samples, as recorded by the thermocouples.

In the starting area of the experiment (the area of thermocouple S-01-05) the samples were heated at a relatively uniform average rate of $1,800{ }^{\circ} \mathrm{C} / \mathrm{h}$ until the reference temperature of $930^{\circ} \mathrm{C}$ was reached. The heating of the rest of the samples was less uniform, with two distinctive intervals for the evolution of temperature. Initially, while the light spot was maintained fixed on the starting position of the experiment, the other samples were heated by conduction. The heating rates of $16.4-1,560^{\circ} \mathrm{C} /$ $\mathrm{h}$ decreased from thermocouples S-01-04 to thermocouples S-01-01. The second phase stars once the light spot is moved along the sample surface, when similar heating rates of $2,700^{\circ} \mathrm{C} / \mathrm{h}$ are reached in all areas exposed to the spot (fig. 5 shows the heating curves indicated by the thermocouples).

The samples were cooled in three distinctive phases. A first phase extends from the initiation of spot movement to the moment when the heating was stopped. Each area of the sample surface started to cool by an average rate of $3,000^{\circ} \mathrm{C} / \mathrm{h}$ as soon as the spot moved away. Once the spot stopped moving, all areas cooled by different rates until their temperature levelled out at $650^{\circ} \mathrm{C}$. These cooling rates are the greater the closer the respective areas are to the sample extremity where the heating was stopped. Around $650^{\circ} \mathrm{C}$ the temperatures in the samples equalize and cooling takes place at an average rate of $5.100^{\circ} \mathrm{C} / \mathrm{h}$ until $170-230^{\circ} \mathrm{C}$. In the last phase cooling is slower in the facility, at rates not interesting for the type of heat treatment.

The comparison of the cooling rates recorded in the samples with those computed based on the CCT diagram

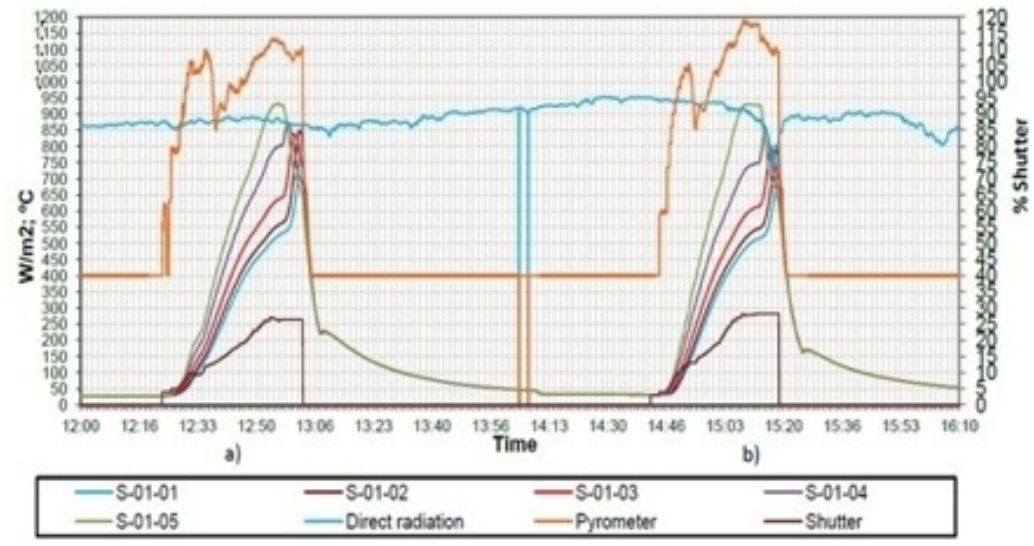

Fig. 5. Working data for experiment 1 : a) sample 1 ; b) sample 2 


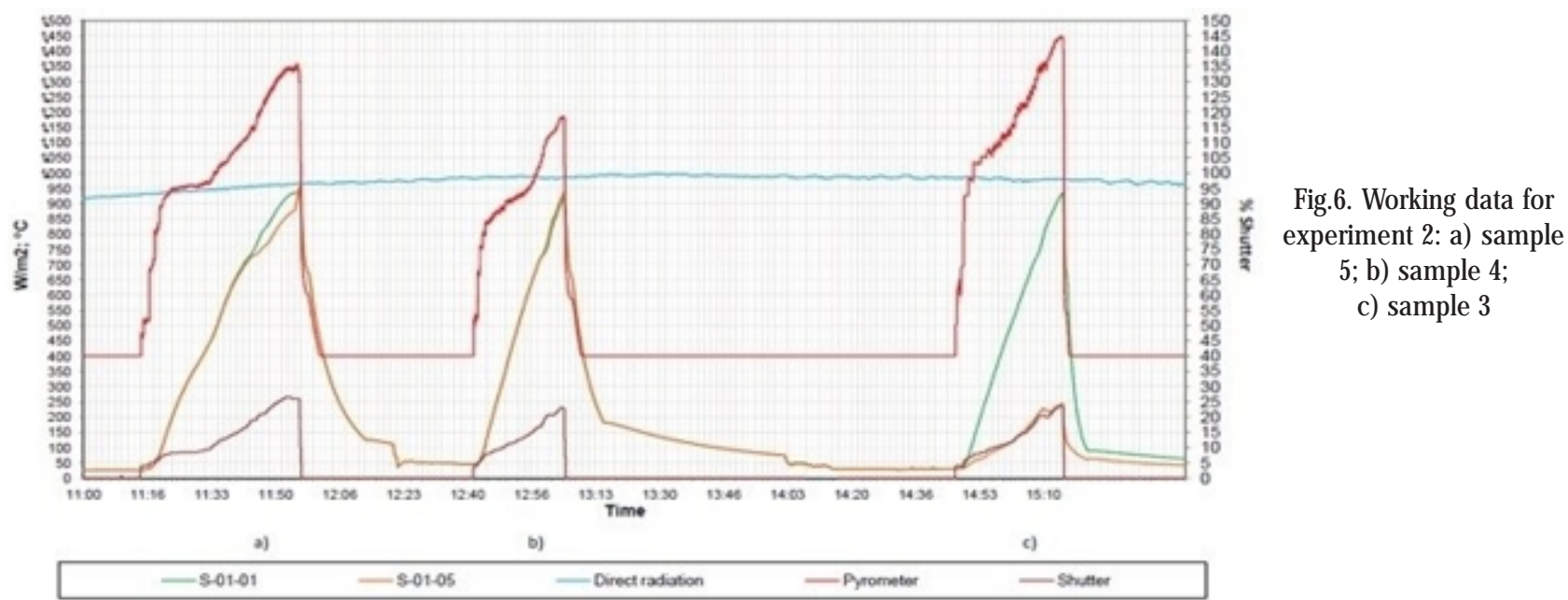

yields the conclusion that the heat treatment performed in this experiment is normalization annealing, determining structures of hardness smaller than 21 HRC (ferritepearlite).

Figure 6 shows the working diagram for experiment 2 .

Sample 3 (fig. 6c) was heated at an average rate of $2.100{ }^{\circ} \mathrm{C} / \mathrm{h}$ up to a temperature of $935^{\circ} \mathrm{C}$. Upon being maintaned for $15 \mathrm{~s}$ at this temperature, the sample cooled at an average rate of $21.840^{\circ} \mathrm{C} / \mathrm{h}$ to a temperature of 700 ${ }^{\circ} \mathrm{C}$; subsequently the cooling rate decreased to about $12.300{ }^{\circ} \mathrm{C} / \mathrm{h}$ until a temperature of $460{ }^{\circ} \mathrm{C}$ was reached.

Sample 4 (fig. 6b) was heated similarly to sample 3, at an average rate of $2,400{ }^{\circ} \mathrm{C} / \mathrm{h}$ up to a temperature of 935 ${ }^{\circ} \mathrm{C}$, where it was maintained for $15 \mathrm{~s}$. Cooling, however, took place at rates somewhat smaller than those of sample 3 , namely at an average rate of $14,100{ }^{\circ} \mathrm{C} / \mathrm{h}$ until $700^{\circ} \mathrm{C}$ and then an average speed of $4,740{ }^{\circ} \mathrm{C} / \mathrm{h}$ up to $460^{\circ} \mathrm{C}$.

The working parameters for sample 5 (fig. 6a) were similar to those of experiment 1 (samples 1 and 2), the spot being moved along the sample surface. In the initial heating area (the area of thermocouple S-01-01) the temperature raising rate was relatively constant, of 1.440 ${ }^{\circ} \mathrm{C} / \mathrm{h}$, up to $936{ }^{\circ} \mathrm{C}$. The rest of the sample heated at the same rate until $450^{\circ} \mathrm{C}$, after which it lagged behind increasingly until the moment when the light spot started to move along the sample surface (the maximum temperature difference between the areas of thermocouples S-01-01 and S-01-05, respectively, was of $60{ }^{\circ} \mathrm{C}$ ). After the light spots started moving, the heating rate in the area of thermocouple S-01-05 increased rapidly causing the temperature to reach $955^{\circ} \mathrm{C}$. The cooling of these samples took place at different rates in the various temperature intervals. Thus in the area of thermocouple S01-01a number of 3 thermal intervals with different cooling rates can be identified: between $936-928^{\circ} \mathrm{C}$ with a rate of $960^{\circ} \mathrm{C} / \mathrm{h}$ (during spot movement towards the other end of the sample), between $928-700{ }^{\circ} \mathrm{C}$ at a rate of $9.120{ }^{\circ} \mathrm{C} / \mathrm{h}$ and between $700-450{ }^{\circ} \mathrm{C}$ at a rate of $3.720^{\circ} \mathrm{C} / \mathrm{h}$. In the area of thermocouple S-01-05 cooling took place in two phases: between $955-700{ }^{\circ} \mathrm{C}$ at an average rate of $10,260^{\circ} \mathrm{C} / \mathrm{h}$ and between $700-450{ }^{\circ} \mathrm{C}$ at an average rate of $3,780{ }^{\circ} \mathrm{C} / \mathrm{h}$. In this case too the heat treatments that were carried out are normalization annealings generating structures of hardness below 21 HRC (ferrite-pearlite).

Figure 7 shows the evolution of temperatures for experiment 3.

The samples were heated as in experiment 2 , and yielded comparable heating rates: sample 6 similar to sample 3, sample 7 similar to sample 4 and sample 8 similar to sample 5 . The variations of solar energy during experimenting with sample 6 (fig. 7a) called for a rerun (fig. 7d). The samples cooled at significantly higher rates than those in experiment 2, while less uniform over the sample length. For sample 7 (fig. $7 \mathrm{~b}$ ) the cooling rate was of $90.000^{\circ} \mathrm{C} / \mathrm{h}$ between the maxim heating temperature of $934^{\circ} \mathrm{C}$ and $334^{\circ} \mathrm{C}$ immediately inferior to the martensitic transformation (as in the CCT diagram of fig. 4). In sample 7 the cooling rates were variable over its length. While in the area of thermocouple S-01-01 the cooling rates fell into the previously mentioned range around $31.920^{\circ} \mathrm{C} / \mathrm{h}$, in the area of thermocouple S-01-05 the cooling rates were around $36.000{ }^{\circ} \mathrm{C} / \mathrm{h}$. Greater differences occurred between the cooling rates of sample 8 . In the first heating area (area of thermocouple S-01-05) the cooling rates in the area of the critical transformations were around $107.100{ }^{\circ} \mathrm{C} / \mathrm{h}$. At the opposite end of the sample the cooling rates were around $46.560^{\circ} \mathrm{C} / \mathrm{h}$. These differences were caused on one hand by the position of the cooling mixture spraying system, and on the other, in the case of sample 8 by a heating deficiency, the maximum temperatures not being uniform in the entire sample (in the area of thermocouple S-01-05 the maximum temperature was of $930{ }^{\circ} \mathrm{C}$, while in the area of thermocouple S-01-01 it was of merely $791^{\circ} \mathrm{C}$ ). In correlation with the CCT diagram of steel it follows that in this experiment the performed heat treatment fell into an intermediary range, applied such as to generate structures

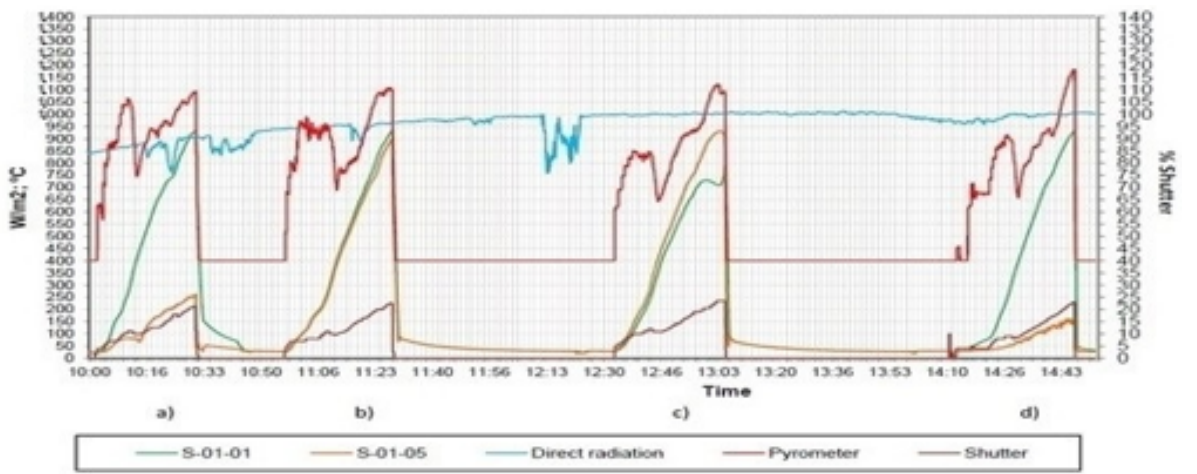

Fig.7.Working data for experiment 3: a) sample 6; b) sample 7; c) sample 8; d) sample 6- rerun 

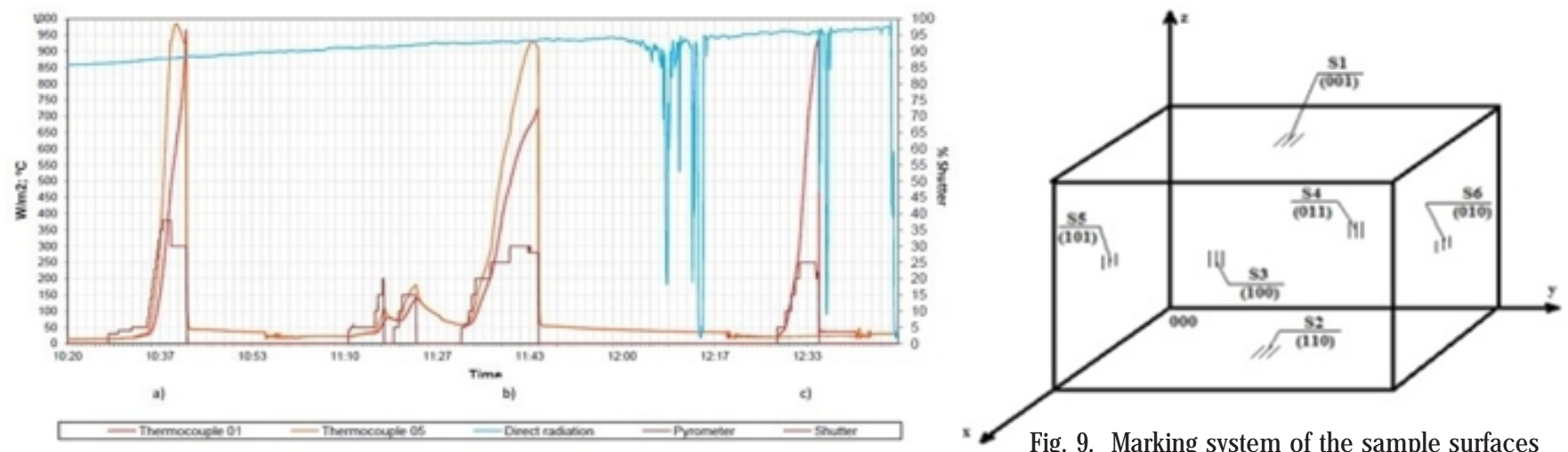

Fig.8. Working data tor experiment 4. a) sample 11; b) sample 10; c) sample 9

Fig. 9. Marking system of the sample surfaces

consisting of nodular perlite, sorbite, troostite, bainite, of hardness between 21 and 55 HRC.

Figure 8 shows the working data for experiment 4 . In this case to the heating was similar to the procedures of experiments 2 and 3 . In sample 9 the maximum heating temperature was not uniform over the sample length $(930$ ${ }^{\circ} \mathrm{C}$ in the area of thermocouple S-01-05 and only $727.7^{\circ} \mathrm{C}$ in the area of thermocouple S-01-01). The cooling rates in this experiment were significantly higher than in the previous experiments: over $480.000^{\circ} \mathrm{C} / \mathrm{h}$ for sample 9, between $278,400-436.800^{\circ} \mathrm{C} / \mathrm{h}$ for sample 10 and between $434.400-460.200^{\circ} \mathrm{C} / \mathrm{h}$ for sample 11 . According to the CCT diagram, in this experiment samples 9 and 11 were hardened, while sample 10 underwent intermediary heat treatment.

\section{Hardness obtained by the applied heat treatment}

The hardness (HRC) of the processed was measured by a selection procedure of the measurement areas. The surfaces of the rectangular block shaped samples were marked with similar indicators to those used in the crystallographic descriptions (Miller Indices) (fig. 9). Subsequently on each surface $0.5 \mathrm{~cm}$ distanced axes parallel to the edges were marked. The hardness was measured at the intersections of these axes and at the intersections of the axes with the lateral edges, respectively.

The hardness on each surface varies between certain limits, as shown in table 2 for all experiments and studied samples.
In certain samples very different hardness values were measured on the same surface. The causes are the working parameters applied in each case.

The small hardness obtained in experiment 1 on the surfaces of samples 1 and 2 are a consequence of their slow cooling in the environment created in the installation after heating. The distribution of hardness on the sample surfaces is correlated with the previously described technological parameters. In the starting area of sample heating the final hardness is smaller, as in a first phase cooling is slow in the ferrite area of the structure (see Figure 5 correlated with the CCT diagram of fig. 4). The lastheated area cools at a higher rate generating a structure with a larger share of pearlite, hence of higher hardness (fig. 10).

This distribution of hardness with the maximum differences along axis [010] can be found on all surfaces of samples 1 and 2 of experiment 1.

Similar hardness values were obtained also in experiment 2. The cooling rates in this case (ranging from $9.120^{\circ} \mathrm{C} / \mathrm{h}$ in sample 5 to $21.840^{\circ} \mathrm{C} / \mathrm{h}$ in sample 3) were smaller than $30.600^{\circ} \mathrm{C} / \mathrm{h}$, the boundary of the ferrite-pearlite area in the CCT diagram. Consequently this treatment was a normalization annealing. A distribution of hardness along the [010] axis similar to that of experiment 1 was observed only in the case of sample 5, where the heating - cooling procedure was similar to that of samples 1 and 2 . The increased air flow used for sample cooling has caused, however, a random distribution of hardness, depending the air flows displacement when contacting the samples. In samples 3 and 4 heated by maintaining the spot in central

Table 2

HARDNESS LIMIT VALUES RECORDED ON THE SAMPLE SURFACES

\begin{tabular}{|c|c|c|c|c|c|c|c|c|}
\hline \multirow[t]{2}{*}{ Item } & \multirow[t]{2}{*}{ Experiment type } & \multirow{2}{*}{$\begin{array}{c}\text { Sample } \\
\text { no. }\end{array}$} & \multicolumn{6}{|c|}{ Surface type / Hardness range [HRC] } \\
\hline & & & S1 & S2 & S3 & S4 & S5 & \$6 \\
\hline 1 & \multirow{2}{*}{ Experiment 1} & 1 & $16-23$ & $14-23$ & $15-23$ & $14-22$ & $17-22$ & $16-21$ \\
\hline 2 & & 2 & $15-28$ & $14-27$ & $10-29$ & $12-29$ & $17-34$ & $11-21$ \\
\hline 3 & \multirow{3}{*}{ Experiment 2} & 3 & $12-23$ & $11-25$ & $13-26$ & $12-31$ & $13-22$ & $15-22$ \\
\hline 4 & & 4 & $12-22$ & $13-19$ & $15-20$ & $13-17$ & $11-20$ & $12-20$ \\
\hline 5 & & 5 & $13-21$ & $13-26$ & $12-22$ & $11-22$ & $10-24$ & $12-25$ \\
\hline 6 & \multirow{3}{*}{ Experiment 3} & 6 & $\begin{array}{c}10-33 / 20- \\
65\end{array}$ & $\begin{array}{l}18-33 / \\
15-62\end{array}$ & $\begin{array}{l}11-23 / \\
18-62\end{array}$ & $\begin{array}{l}21-32 \\
24-65\end{array}$ & $\begin{array}{l}13-26 / \\
25-33\end{array}$ & $\begin{array}{l}20-30 / \\
31-48\end{array}$ \\
\hline 7 & & 7 & $18-43$ & $11-28$ & $18-35$ & $12-41$ & $14-24$ & $19-28$ \\
\hline 8 & & 8 & $18-65$ & $20-35$ & $21-64$ & $13-33$ & $24-30$ & $14-33$ \\
\hline 9 & \multirow{3}{*}{ Experiment 4} & 9 & $55-67$ & $27-64$ & $61-66$ & $57-66$ & $57-67$ & $27-67$ \\
\hline 10 & & 10 & $35-64$ & $34-67$ & $35-68$ & $54-72$ & $50-70$ & $43-65$ \\
\hline 11 & & 11 & $25-65$ & $22-63$ & $25-67$ & $24-64$ & $50-65$ & $22-33$ \\
\hline
\end{tabular}



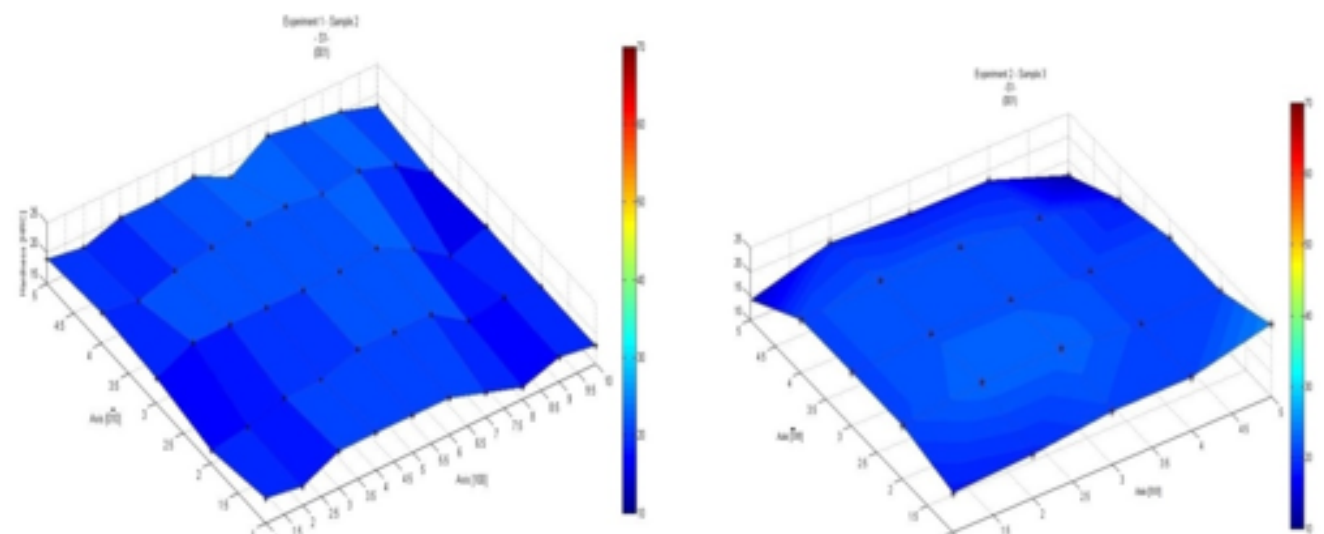

Fig.10. Hardness distribution on the heated surface of sample 2. The light spot moved along axis [010], in the median area of the surface

position, the maximum hardness was obtained in these areas. It can be assumed that the marginal areas of the samples were insufficiently heated (in the austenitic area) for a correct heat treatment (fig. 11).

The procedure deployed in experiment 3 has determined large variations in the cooling rates of the sample material in its various areas, because of the actual impacting modality of the sprayed $\mathrm{Ar}$ and water mixture onto the samples. This caused large variations of the type of heat treatment and consequently of the obtained hardness (example in figure 12 for sample 6).
The correlation of the hardness distributions on all sample surfaces reveals that the applied cooling has ensured rates adequate for hardening only in a certain area of the part, what does not render iteligible for this hardening method. The same distribution of hardness is found also in the case of samples 7 and 8. Further cooling is inefficient in sample 7, as it did not reach the values required for hardening the material.

In experiment 4 the cooling rates were sufficiently high for hardening. Sample 9, heated only in the central area, without spot displacement, was plunged into Ar bubbled
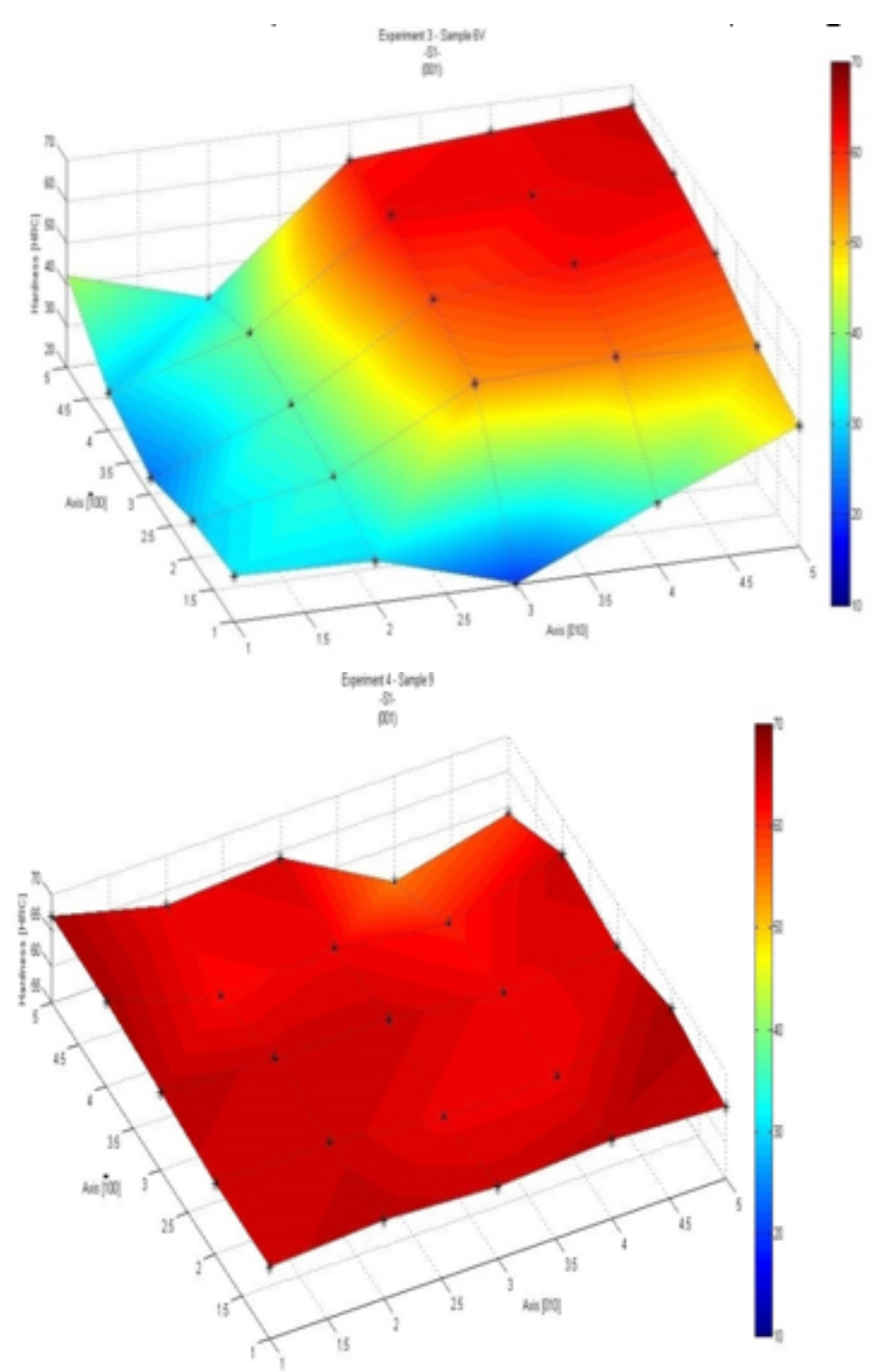

Fig. 11. Hardness distribution on the heated surface of sample 3. The light spot was kept fixed in the central area of the sample surface 


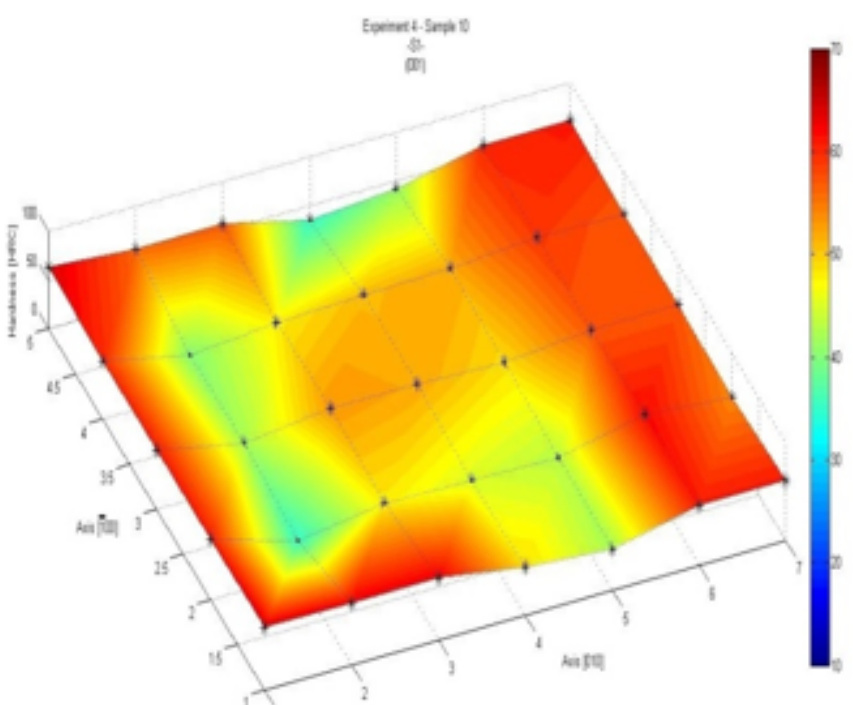

Fig. 13. Hardness distribution in the heated surface of sample 9. The light spot was moved along axis [010] in the median area of the surface

water, and developed typical hardening values of the hardness in nearly its entire volume (fig. 13).

In this case too differences may occur between the cooling rates of certain sample areas, depending on the specifics of the interaction between the cooling medium and the sample. Such differences were noted in the case of samples 10 and 11, where the spot was moved along the sample surface (fig. 14). The differences are a consequence mainly of the temperature of each sample area at the time of plunging into the cooling medium. As temperature control is available, a controlled distribution of the properties can be generated along a certain direction in the material (the case of sample 11, fig. 14).

Sample 11 was heated such as to generate along the sample length a transition from hardened to unhardened structures, yielding a distribution of hardness as shown in figure 14

As in the rest of the analysed samples, in this case too, a good correlation was noted between the hardness of the sample lateral surfaces, what suggests the same type of distribution also in the volume of the treated samples.

The distribution of hardness in the tested samples reveals a good correlation of the hardness values with the recorded cooling rates. Further the repeatability of the values can be noticed under similar treatment conditions. This indicates the possibility of adapting the solar furnace accessories such as to perform the desired heat treatment with a satisfying precision by adjusting the mobility parameters of the test table and the cooling conditions of the materials, respectively. The data for such research can benefit from an important addition by the mathematical modelling and computer simulation of the thermal processes in the samples. The authors of the research discussed in this paper have already completed the first set of simulations using the presented experimental data for verification. This will be further explored in future research.

The analysis of the hardness values obtained by the completed experiments places them higher than those indicated in the CCT diagram of steel for similar cooling rates. For example sample 9 of experiment 4 has areas of hardness 65-67 HRC, sensibly greater than those typical for this steel upon hardening ( $55-60 \mathrm{HRC})$. This tendency was noticed also in similar research conducted on steel of the same category [5], as well as on alloyed steels [7].

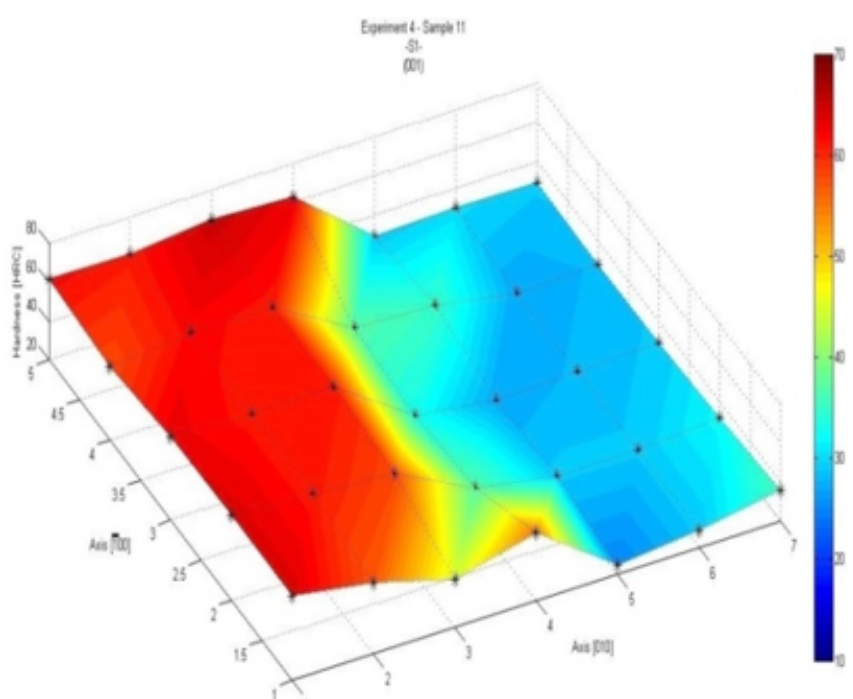

Fig. 14. Hardness distribution on the heated surface of sample 11 The light spot was moved along axis [010] in the median area of the surface

This yields the conclusion that hardness is determined not solely by the structure resulting upon the hardening treatment. A further contributor is the internal stress state of the material, particularly in the proximity of the exterior surfaces, where the action of the energy source differs from that of conventional sources, especially in relation to the rate of heat transfer.

\section{Conclusions}

The completed experiments prove the possibility of using solar energy in form of direct heating with a light spot, in order to carry out various heat treatments of metallic materials, in the present case of steels. By controlling the sample heating and cooling process parameters the specific conditions for a wide range of heat treatments can be achieved, thus ensuring the desired structures and properties of materials.

The distribution of temperature at the heating of materials can be controlled by the positioning and displacement of the light spot. It can be observed that in the case of products of relatively great lengths, a stationary distribution of temperature in materials is achieved upon moving the light spot over their surface (fig. 5 for samples 1 and 2 of experiment 1 ). This can be deployed within the context of conducting specific superficial treatment, like superficial hardening, by ensuring also a stationary adequate cooling, displaceable in combination with the light spot.

The conducted research has revealed ensuring of an adequate cooling regime as more difficult than of a heating regime. It can be asserted that with the increasing penetration depth of the heat, this inconvenient amplifies and is likely to determine significant non-uniformities of structure and properties.

As established in experiment 4 , in addition to adequately hardened structures also a controlled combination of hardened and unhardened areas in the same products can be achieved (generation of property gradients in the same product).

The information resulted from the present research is an important base for establishing the working variants (constructive specifics of the accessories, working parameters), such as to enable the desired heat treatment for a steel of the analysed category for products of similar dimensions and geometry. 
At cooling rates corresponding to hardening treatments, the obtained hardness of the samples has reached higher values than typical for this type of steel. This aspect is to be explored by further analyses of the samples. It can be assumed, however, that it is the consequence to a state of higher internal stress in the treated areas, following to the high heating-cooling rates that increase the hardness of the typical hardening structures. A possible significant role can also come to the increase of dislocation density.

It has been proved that by using solar energy in applying terms treatment to steel 1.1730 cannot emit greenhouse gas (as well as gas fuels used in classical technology) and productivity rise 4 times what it makes us state that this technology is a clean and efficient one with a high efficiency.

Further studies are necessary to automate and deploy this process.

Developing new clean technologies for materials processing, based on one of the main sources of energy available, solar radiation, its use seeks to minimize the environmental impact of the material processing, as well as the industrial processes, in front of the use of fossil fuels.

Acknowledgements: We hereby acknowledge the structural founds projectPRO-DD (POS-CCE, 0.2.2.1., ID 123, SMIS2637, ctr. No 11/2009) for providing the infrastructure used in this work and for the Financial support by the Access to Research Infrastructures activity in the 7th Framework Programme of the EU (SFERA Grant Agreement n. 312643 CIEMAT-PSA).

\section{References}

1.CAMBRONERO, L.E.G., RUIZ-IGLESIAS, J., CAÑADAS, I., MARTÍNEZ, D., , Proceedings of World Powder Metallurgy Congress \& Exhibition PM 2010, 2, 2010, p. 173.

2.*** Dorrenberg Edelstahl, Material no. 1.1730 Code C45U, 2013, http://www.doerrenberg.de/uploads/tx_c1xldownloads/1.1730_en.pdf (Accessed 4.11.2017).

3.FERNANDEZ, B.J., LOPEZ, V., VAZQUEZ, A.J., MARTINEZ, D., Solar Energy Mater. Solar Cells, 53, 1998, p. 153.

4.FERRIERE, A., FAILLAT, G., GALASSO, S., BARRALLIER L., MASSE, J.E., J ournal of Solar Energy Engineering: Transactions of the ASME $121,1,1999$, p. 36.
5.FLAMANT, G., BALAT-PICHELIN, M., 2010, http://www.eolss.net/ sample-chapters/c08/e6-106-17.pdf, (Accesed 4.11.2017).

6.FRANCK, M., OBERLANDER B.C., CELLIS, J.P., ROOS, J.R., , Solar Energy Mater. Solar Cells, 31, 1993, p. 401.

7.HERRANZ, G., RODRIGUEZ G.P., Uses of Concentrated Solar Energy in Materials Science, Solar Energy Book, InTech, 2010, p. 23.

8.KARALIS, D.G., PANTELIS D.I., PAPAZOGLOU, V.J ., Solar Energy Materials \& Solar Cells, 86, 2005, p. 145.

9.LLORENTE, J., VAZQUEZ, A.J., Materials Chemistry and Physics, 118,2009, p. 86.

10.PITTS, J.R., STANLEY, J.T., FIELDS, C.L., Proceedings of the 4th International Symposium on Research Development and Applications of Solar Thermal Technology, Santa Fe NM, 6, 1988, p. 459.

11.RODRIGUEZ, G.P., LOPEZ, V., VAZQUEZ, A.J., DE DAMBORENEA, J.J., KIRKPATRICK A., WOREK, W., Solar Engineering, ASME, New York, 1993, p. 325.

12.RODRIGUEZ, G.P., LOPEZ V., DE DAMBORENEA, J.J., VAZQUEZ, A.J., Solar Energy Materials and Solar Cells, 37, 1995, p. 1.

13.RODRIGUEZ, J., CANADAS, I., ZARZA, E., Energy Procedia, 49, 2014, p. 1511.

14.ROMERO-NIEVA, F., Final degree Project ETSII-UCLM Ciudad Real (in Spanish), 2002.

15.SAMOILA, C., DRUGA L., STAN, L., Didactical and Pedagogical Publishing House Bucharest, Annex 5.2 (in Romanian), 1983, p. 131. 16.SAMOILA, C., BOT D., Transilvania from Brasov Publishing House, (in Romanian), 1979, p. 145.

17.SARVER, T., AL-QARAGHULI, A., KAZMERSKI LAWRENCE, L., Renewable and Sustainable Energy Reviews, 22, 2013, p. 698.

18.STANLEY, J.T., PITTS, J.R., FIELDS, C.L., YAZICI, R.M., Materials Chemistry and Physics, 1989, p. 43.

19.STEFANESCU, CL., STEFANESCU, D.M., Handbook casting, Tehnica Publishing House, Bucharest (in Romanian), 1972, p. 265.

20.TROMBE, F., FOEX, M., Solar Energy, 1, 1957, p. 63.

21.VAN INGELGEM, Y., VANDENDAEL, I., VAN DEN BROEK, D., HUBIN, A., VEREECKEN, J ., Electrochimica Acta, 52, 2007, p. 7796.

22.VAZQUEZ, A.J., RODRIGUEZ, G.P., DE DAMBORENEA, J. J ., Solar Energy Materials, 24 1991, p. 751.

23.WILSON, A.D., ASTM STP, 1361, 1991, p. 73.

24.YANG, Y., TORRANCE, A.A., RODRIGUEZ, J., Solar Energy Solar Cells, 40, 1996, p. 103.

25.ZHONG KUI, Y., JIN TANG, L., Surf. Eng., 3, 1987, p. 41.

Manuscript received: 21.12 .2018 